\title{
Fishery Interactions Between Long-finned Squid (Loligo pealei) and Butterfish (Peprilus triacanthus) off the Northeast USA
}

\author{
Anne M. Lange \\ Maryland Department of Natural Resources, Chesapeake Bay Research and Monitoring \\ 580 Taylor Avenue, Annapolis, Maryland 21401, USA \\ and \\ Gordon T. Waring \\ National Marine Fisheries Service, Northeast Fisheries Science Center * \\ Woods Hole Laboratory, Woods Hole, Massachusetts 02543, USA
}

\begin{abstract}
The domestic butterfish (Peprilus triacanthus) fishery off the Northeast USA has increased in importance in recent years, to the extent that the quantity allocated to foreign countries fishing within USA waters has been decreased to by-catch levels. This restriction resulted in closure of a portion of the foreign squid fishery in 1985, when the by-catch quota for butterfish was exceeded. This analysis is designed to determine co-occurrence between long-finned squid (Loligo pealei) and butterfish particularly in directed fisheries for each species with a view that areal, diel, and/or seasonal regulations of these fisheries may be feasible to reduce the potential adverse effects of high by-catch rates.

Squid and butterfish exhibited high degrees of overlap in temperature and depth preferences as indicated by seasonal and spatial distribution data from research and fishery sources. Commercial fishery data, however, suggested that by-catch of butterfish in the directed squid fishery can be maintained at relatively low levels $(\leqslant 6 \%)$, when the fishery was prosecuted offshore during the winter. The domestic USA fishery, operating with effort directed at either species at various times of the year, has not been limited as to by-catch of either species. If a need develops, it is likely that seasonal and areal management measures could result in significant reductions in the by-catch of either species.
\end{abstract}

\section{Introduction}

The long-finned squid (Loligo pealei) and the butterfish (Peprilus triacanthus) are found along the Atlantic coast of North America from Newfoundland to Florida, and are commercially important from Southern New England to Cape Hatteras. Seasonally their concentrations are found in various localized geographic areas. North of Cape Hatteras, the squid and butterfish migrate inshore and northward during the spring and summer, and squid spawn in shallow nearshore areas between the Chesapeake Bay and Cape Cod. In late autumn both species begin to move offshore to the edge of the shelf as the northern inshore waters cool.

Directed offshore fisheries for long-finned squid have existed off the Northeast USA since the early1970s, conducted by the distant-water fleets of Spain, Japan and Italy. The USA domestic catches of squid were taken primarily as a by-catch until the late-1970s when the directed fisheries on the inshore spawning populations began. An offshore domestic trawl fishery for butterfish has existed since the early-1970s, while the offshore foreign fishery for butterfish began in conjunction with the development of the squid fishery. Prior to adoption of the Magnuson Fishery and Conservation Management Act in 1976, butterfish were taken by foreign vessels either as by-catch in the squid fishery, or as a directed catch in a "switch" fishery. The "switch" fishery was done by Japan where squid were taken during the day and butterfish during the night.

In recent years, as the importance of the USA butterfish fishery increased, the amount of butterfish allocated to foreign fisheries has decreased to minimal by-catch levels. This decreased allocation has restricted the foreign squid fisheries and in autumn 1985, when their by-catch quota was exceeded, it resulted in closure of the fishery to the Spanish fleet.

The analyses presented here are intended to determine when and where the co-occurrence of longfinned squid and butterfish is most likely to result in high levels of butterfish by-catch in directed squid

\footnotetext{
* Formerly Northeast Fisheries Center.
} 
fisheries. Then adjustments in the patterns of fishing in the squid fishery could be made to reduce the butterfish by-catch. Data sources include the National Marine Fisheries Service (NMFS), Northeast Fisheries Center (NEFC), spring, summer and autumn bottom trawl surveys (1976-85); tow-by-tow catch logs for the foreign fleets obtained by the NMFS Foreign Fishery Observer Program during 1984; and NEFC interview data from the USA domestic fishery.

\section{Methods and Materials}

\section{NEFC bottom trawl survey data}

Routine bottom trawl surveys are conducted seasonally by NEFC in continental shelf waters from southern Nova Scotia to North Carolina (Azarovitz, 1981). Survey stations are selected using a stratified random sampling scheme. A $30-\mathrm{min}$ tow is conducted at each randomly selected station. Stratum boundaries (Fig. 1) are based primarily on depths, and to some extent, bottom type. Detailed descriptions of the survey design, sampling procedures, equipment and data processing for NEFC bottom trawl surveys are provided in Grosslein (1969) and Azarovitz (1981). Surveys employed a 36-Yankee otter trawl except during spring 1976-81 when a larger 41-Yankee trawl was used (Azarovtiz, 1981). Spring and autumn surveys conducted during 1976-85 and summer surveys during 1977-81 were used in this analysis.

Survey data were aggregated by depth, time, area and season to determine if the sample allocation might have resulted in biased population estimates, and to evaluate possible differences in distributions of tows due to these factors. Data were grouped into five depth ranges $(<27 \mathrm{~m}, 27-55 \mathrm{~m}, 56-110 \mathrm{~m}, 111-185 \mathrm{~m}$ and $>185 \mathrm{~m})$. Three time periods were also defined: day (08:01-16:00 hr), night (20:01-04:00 hr) and dawn/dusk (04:01-08:00 and 16:01-20:00 hr). For comparison of survey results with those from the commercial fishery data, sample locations were grouped by statistical area (Fig. 1) resulting in seven area groups (46-63). The regrouping of survey data by these variables (area, depth and time) was possible with minimal bias because of the stratified random design of the survey.

A total of 3633 spring, 1228 summer, and 3844 autumn tows were used and these data were summarized (number and percentage) by season, area, time and depth (Table 1). The total number of tows within an area was generally proportional to the size of the area (square miles) and tows were about equally distributed among time periods. Differences in distribution of number of tows among depths resulted from proportional allocation of survey stations by size of strata, where the continental slope drops off rather quickly, deeper strata tended to be smaller (Fig. 1). Summer surveys generally focused on shallow water strata $(<111 \mathrm{~m})$, because of the special interests of those surveys.

The implication of harvesting large versus small individuals was considered important, thus, survey catches for each species were analyzed for all individuals, and by two size-groups. For squid these sizegroups represent prerecruits $(\leqslant 8 \mathrm{~cm})$ and fishable sizes (recruits $>8 \mathrm{~cm}$ ). Small butterfish were defined as those $\leqslant 12 \mathrm{~cm}$ (approximately 1 year old) and large individuals as those $>12 \mathrm{~cm}$. Survey data were analyzed separately by season. Factors considered in the analysis include the statistical area where the station

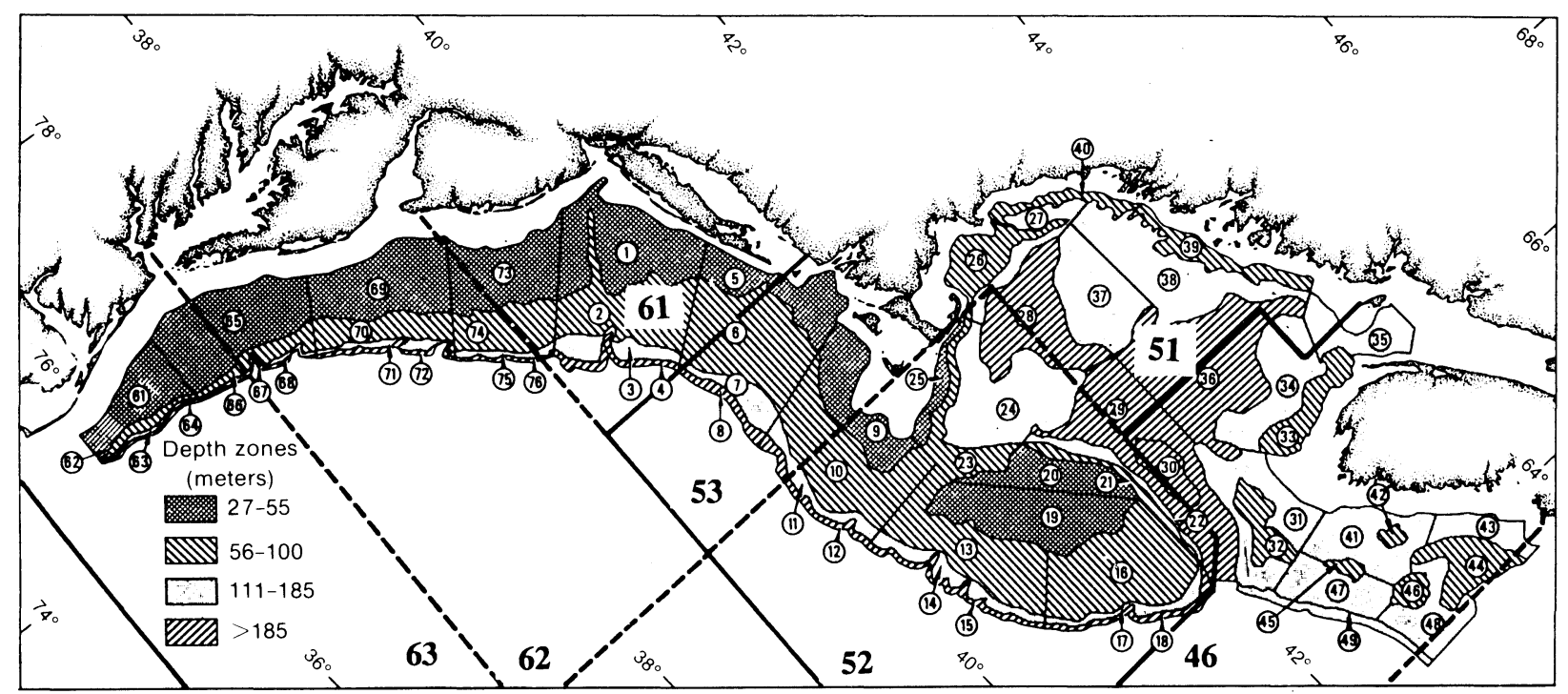

Fig. 1. Area off the Northeast United States showing NMFS, NEFSC bottom trawl survey strata and statistical areas 
TABLE 1. Distribution of NMFS bottom trawl survey tows (1976-85) among areas, time periods and depth ranges by season (in number and percentage).

\begin{tabular}{|c|c|c|c|c|c|c|}
\hline & \multicolumn{2}{|c|}{ Spring } & \multicolumn{2}{|c|}{ Summer } & \multicolumn{2}{|c|}{ Autumn } \\
\hline & Number & Percent & Number & Percent & Number & Percent \\
\hline Area & & & & & & \\
\hline 46 & 350 & 9.6 & 0 & 0.0 & 318 & 8.3 \\
\hline 51 & 509 & 14.0 & 230 & 18.7 & 588 & 15.3 \\
\hline 52 & 953 & 26.2 & 349 & 28.4 & 1153 & 30.0 \\
\hline 53 & 320 & 8.8 & 98 & 8.0 & 277 & 7.2 \\
\hline 61 & 654 & 18.0 & 264 & 21.5 & 663 & 17.3 \\
\hline 62 & 544 & 15.0 & 183 & 14.9 & 522 & 13.6 \\
\hline 63 & 303 & 8.3 & 104 & 8.5 & 323 & 8.4 \\
\hline
\end{tabular}

Time Period

$\begin{array}{lllllll}\text { Day } & 1191 & 32.8 & 410 & 33.4 & 1241 & 32.3 \\ \text { Night } & 1214 & 33.4 & 404 & 32.9 & 1285 & 33.4 \\ \text { Dawn/dusk } & 1228 & 33.8 & 414 & 33.7 & 1318 & 34.3\end{array}$

\begin{tabular}{rrrrrrr} 
Depth (m) & \multicolumn{7}{l}{} \\
& & & & & & \\
$0-26$ & 742 & 20.4 & 385 & 31.4 & 770 & 20.0 \\
$27-55$ & 732 & 20.2 & 354 & 28.8 & 730 & 19.0 \\
$56-110$ & 1006 & 27.7 & 359 & 29.2 & 1096 & 28.5 \\
$111-185$ & 650 & 17.9 & 95 & 7.7 & 687 & 17.9 \\
$>185$ & 503 & 13.8 & 35 & 2.9 & 561 & 14.6 \\
\hline Total & 3633 & $(100.0)$ & 1228 & $(100.0)$ & 3844 & $(100.0)$ \\
\hline
\end{tabular}

was located (Fig. 1), depth $(\mathrm{m})$, bottom water temperature $\left({ }^{\circ} \mathrm{C}\right)$ and time period of day.

Distribution of each species/size-group was analyzed by season, area, depth and time period to determine patterns of co-occurrence among the various species/sizes. The fine spatial structure of species distribution were examined in relation to patterns of species co-occurrence, i.e. the differences between co-occurrence within tows as well as summed catches within the same season-area-depth-time block. By analyzing patterns of co-occurrence in relation to environmental preferences, it was possible to evaluate the potential for technological interaction (i.e. by-catch) among species/sizes.

Annual variations in distribution associated with changes in abundance were examined by computing annual indices of abundance and corresponding indices of spatial dispersion for each species/size-group, using the autumn survey data. The southern New England and Mid-Atlantic regions, the primary areas of distribution, of the species/size-groups were used (areas 53-63). Mean numbers-per-tow (index of relative abundance), standard deviation (sd) and coefficients of variation ( $\mathrm{cv}=\mathrm{sd} /$ mean) of the mean were computed (Table 2). Two statistics related to the ability of the species/size-group to disperse in relation to changes in density (abundance) were also computed. The first is the proportion of tows (PZ) not containing the given species/size-group; the second term is an index of spatial dispersion (DI) (Green, 1966; Elliott, 1977):

$$
D I=\left(\left(s^{2} / \bar{X}\right)-1\right) /((\Sigma n)-1)
$$

where $s^{2}=$ variance of the number-per-tow,

$$
\overline{\mathrm{x}}=\text { mean number-per-tow, }
$$$$
\mathrm{n}=\text { total numbers sampled. }
$$

The index DI ranges from 1, when the stock exhibits maximum spatial contagion (i.e. all $\mathrm{n}$ are in one tow for a large $n)$, to 0 for a random distribution, and tends to $-(1 /(n-1))$ for a distribution with maximum regularity (Elliott, 1977).

The potential for overlap in the distributions of various species/size-groups is no doubt related to temperature and depth preferences exhibited by each. These "preferences" were analyzed by computing the distribution (by $10 \mathrm{~m}$ intervals) and bottom temperatures (in whole ${ }^{\circ} \mathrm{C}$ intervals) of capture for each sizegroup, by season. Only tows in areas 53-63 were used in this analysis. Records which did not contain temperature data were excluded from the analysis. Seasonal mean depth (or temperature) was computed by weighting the midpoint of each depth (or temperature) interval by the number-per-tow index for each species/size-group in that interval, summing over all intervals, and dividing by the total number-per-tow index over all intervals:

$$
\bar{x}=\sum_{k=1}^{n} \quad X_{k} N_{i j k} / \Sigma_{k=1}^{n} N_{i j k}
$$


TABLE 2. Catch statistics for large and small long-finned squid and butterfish during NMFS autumn bottom trawl surveys, $1976-85$. Mean is the number-per-tow, SD is standard deviation, CV is coefficient of variation (sd/mean), PZ is the proportion of tows not containing the species/size class, and $\mathrm{DI}$ is the dispersion index $\left(\mathrm{sd}^{2} /\right.$ mean-1)/N-1)).

\begin{tabular}{|c|c|c|c|c|c|c|c|c|c|c|}
\hline \multirow{2}{*}{$\begin{array}{l}\text { Species/size- } \\
\text { group parameter }\end{array}$} & \multicolumn{10}{|c|}{ Year } \\
\hline & $\overline{1976}$ & 1977 & 1978 & 1979 & 1980 & 1981 & 1982 & 1983 & 1984 & 1985 \\
\hline \multicolumn{11}{|l|}{ Squid/large } \\
\hline Mean & 96.08 & 79.46 & 62.40 & 35.56 & 78.42 & 59.16 & 55.65 & 110.59 & 104.90 & 107.90 \\
\hline SD & 332.14 & 227.45 & 142.38 & 90.62 & 138.20 & 143.56 & 124.85 & 229.33 & 271.62 & 253.15 \\
\hline $\mathrm{CV}$ & 3.46 & 2.86 & 2.28 & 2.55 & 1.76 & 2.43 & 2.24 & 2.07 & 2.59 & 2.35 \\
\hline$P Z$ & 0.28 & 0.23 & 0.30 & 0.34 & 0.18 & 0.25 & 0.18 & 0.13 & 0.10 & 0.08 \\
\hline DI & 0.07 & 0.05 & $0 ., 03$ & 0.03 & 0.02 & 0.03 & 0.03 & 0.03 & 0.05 & 0.09 \\
\hline
\end{tabular}

\section{Squid/small}

SD

CV

PZ

DI

\section{Butterfish/large}

Mean

SD

CV

$\mathrm{PZ}$

DI

\section{Butterfish/small}

$\begin{array}{lrrrrrrrrrr}\text { Mean } & 97.12 & 46.43 & 146.43 & 172.66 & 158.39 & 237.27 & 141.06 & 749.27 & 335.84 & 318.59 \\ \text { SD } & 281.61 & 149.69 & 403.30 & 446.09 & 421.66 & 581.78 & 417.36 & 2769.07 & 1014.54 & 1068.89 \\ \text { CV } & 2.90 & 3.22 & 2.75 & 2.58 & 2.66 & 2.45 & 2.96 & 3.70 & 3.02 & 3.36 \\ \text { PZ } & 0.39 & 0.45 & 0.34 & 0.32 & 0.34 & 0.28 & 0.27 & 0.34 & 0.17 & 0.31 \\ \text { DI } & 0.05 & 0.06 & 0.04 & 0.04 & 0.05 & 0.03 & 0.05 & 0.08 & 0.07 & 0.19\end{array}$

where $\bar{x}=$ mean depth or temperature at capture;

$X_{k}=$ the mid-point of the depth or temperature interval $(k=1,2, \ldots, n)$;

$N_{i j k}=$ the catch-per-tow, in numbers, of species $\mathrm{i}$, size group $\mathrm{j}$, in the depth or temperature interval $\mathrm{k}$.

Seasonal overlaps in temperature and depth preferences for the different species/size-groups were also characterized as the intersection of normal distributions which approximate the distribution of the species/size-group along temperature or depth continua (May, 1973; Murawski and Finn, 1988) as:

$$
A_{i j}=C_{i j} \exp \left[-d^{2} / 2\left(w_{i}^{2}+w_{i j}^{2}\right)\right]
$$

where $C_{i j}=i s$ the normalized constant $\left[\left(2 w_{i} W_{j}\right]\right.$

$$
\begin{aligned}
& \left.\left.\left(w_{i}^{2}+w_{i}^{2}\right)\right) 1 / 2\right] \\
& \text { If } w_{i}=w_{i} \text { then } C_{i j}=1 \text {, }
\end{aligned}
$$

and $\quad A_{i 1}=$ overlap coefficient between species/size $\mathrm{i}$ and $\mathrm{j}$,

$\mathrm{d}=$ 'distance' between mean environmental values for species/size $i$ and $j\left(X_{i}-X_{j}\right.$, from equation 2),

\begin{abstract}
$\mathrm{w}=$ standard deviations of the resource utilizations of species/size $i$ and $j$ along temperature or depth continuum (May, 1973).
\end{abstract}

Coefficients of overlap $\left(A_{i j}\right)$ range from 0 (no overlap) to 1 (complete overlap). These coefficients were computed for each species/size-group pair for depth and temperature, separately.

Even though the different species or species/sizegroups may be found in the same areas, depths and time periods during a season, they may not necessarily be co-distributed, due to small scale spatial differences. Likewise, they may not necessarily be caught together by fishing gear due to differences in catchability and gear avoidance among the species/size-groups. Annual fluctuations in abundance could also produce variations in the relative sizes of the catches of each group in a given tow. Therefore, the co-occurrence of species/size pairs was analyzed based on their presence or absence in each tow, rather than on a quantitative basis. The proportion of tows containing at least one individual of each species/size-group in the pair, by season and over all seasons, was examined. 


\section{Commercial data}

Foreign Fishery Observer Data: By-catch of butterfish from the 1984 squid directed foreign fishery off the Northeastern USA were analyzed based on individual records of 2353 tows. Data were grouped by country, area and month. Individual trips were randomly subsampled from the total data set by country-areamonth strata, to provide representative samples of the fishery. All tows within selected trips were included. The data for 1984 represented the most recent complete year available for analyses, and although it may not have been most representative of the behaviour of the fishery over time, it reflected the current conditions for the foregin fleet.

These data covered the months of January-March and August-December. Records were grouped into three time periods and five depth zones (as described for NEFC survey data), five areas (Fig. 2), and by country (Italy, Japan and Spain). Summaries of the number of tows by month, time period, depth zone, area and country are presented in Table 3 . Also provided are the numbers and percentages of tows in each category which caught squid and those which took butterfish.

USA Interview Data Analyses: Data from the USA domestic fishery during 1984 were also analyzed to evaluate interactions between the catches of squid and butterfish. Interview data were obtained by NMFS port agents from a subset of the trip landings in New England and Mid-Atlantic ports. These data include the

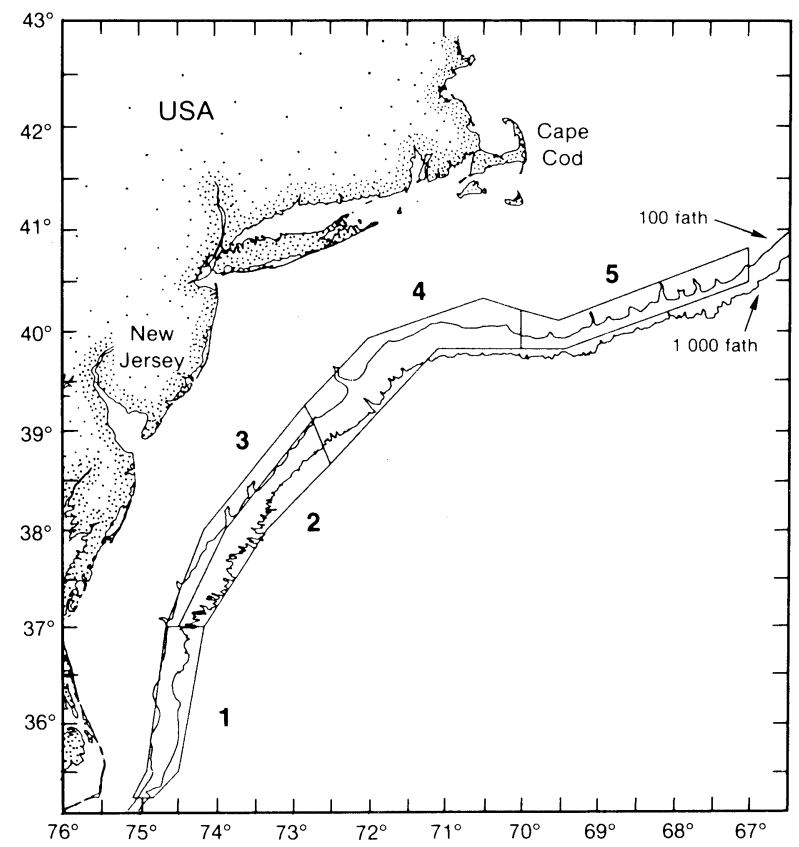

Fig. 2. Northwest Atlantic fishery areas (windows) used by the foreign fleet fishing in USA waters to report catch statistics during 1984. catch (in weight) by species, trip dates and fishing location. Only trips with squid and/or butterfish catches were considered in this analysis. These data were summarized by month, to $10^{\prime}$ (latitude/longitude) quadrants and plotted to show where catches were dominated by either species. Figure 3 gives representative plots for each quarter from the monthly series.

\section{Results}

\section{NEFC bottom trawl survey data}

Distributions of each species/size-group were summarized by area, depth, and time period of day for spring (Fig. 4), summer (Fig. 5), and autumn (Fig. 6). The percentages in Fig. 4-6 represent the relative distribution of stations with a species/size-group; the areas

TABLE 3. Summary of number and percentage of tows from the foreign squid fishery which contained long-finned squid or butterfish, by fishing window, country, month, time period and depth range. Data are from a subset of 1984 NMFS Foreign Fishery Observer Program trip logs.

\begin{tabular}{cccc}
\hline $\begin{array}{c}\text { Block- } \\
\text { value }\end{array}$ & $\begin{array}{c}\text { Total No. } \\
\text { of tows }\end{array}$ & Long-finned squid & Butterfish \\
\cline { 4 - 6 } & Number Percent & Number Percent
\end{tabular}

\section{Fishing}

window

$\begin{array}{cr}1 & \\ 2 & 251 \\ 3 & 1364 \\ 4 & 670 \\ 5 & \\ \text { NK }^{\mathrm{a}} & \end{array}$

7
251
1364
670
60
1

6
237
1345
648
59
1

85.7
94.4
98.6
96.7
98.3
100.0

Country
Italy

Japan

Spain

Month

Jan

Feb

Mar

Aug

Sep

Oct

Nov

Dec

Time period

Day

Dawn/dusk

Night

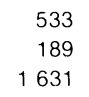
530
184

1582
Depth range

\begin{tabular}{lrrrrr}
$27-55 m$ & 1 & 1 & 100.0 & 1 & 100.0 \\
$56-110 m$ & 1326 & 1323 & 99.8 & 460 & 34.7 \\
$111-185 m$ & 969 & 932 & 96.2 & 747 & 77.1 \\
$>185 m$ & 57 & 40 & 70.2 & 17 & 29.8 \\
\hline
\end{tabular}

a From an unknown area 

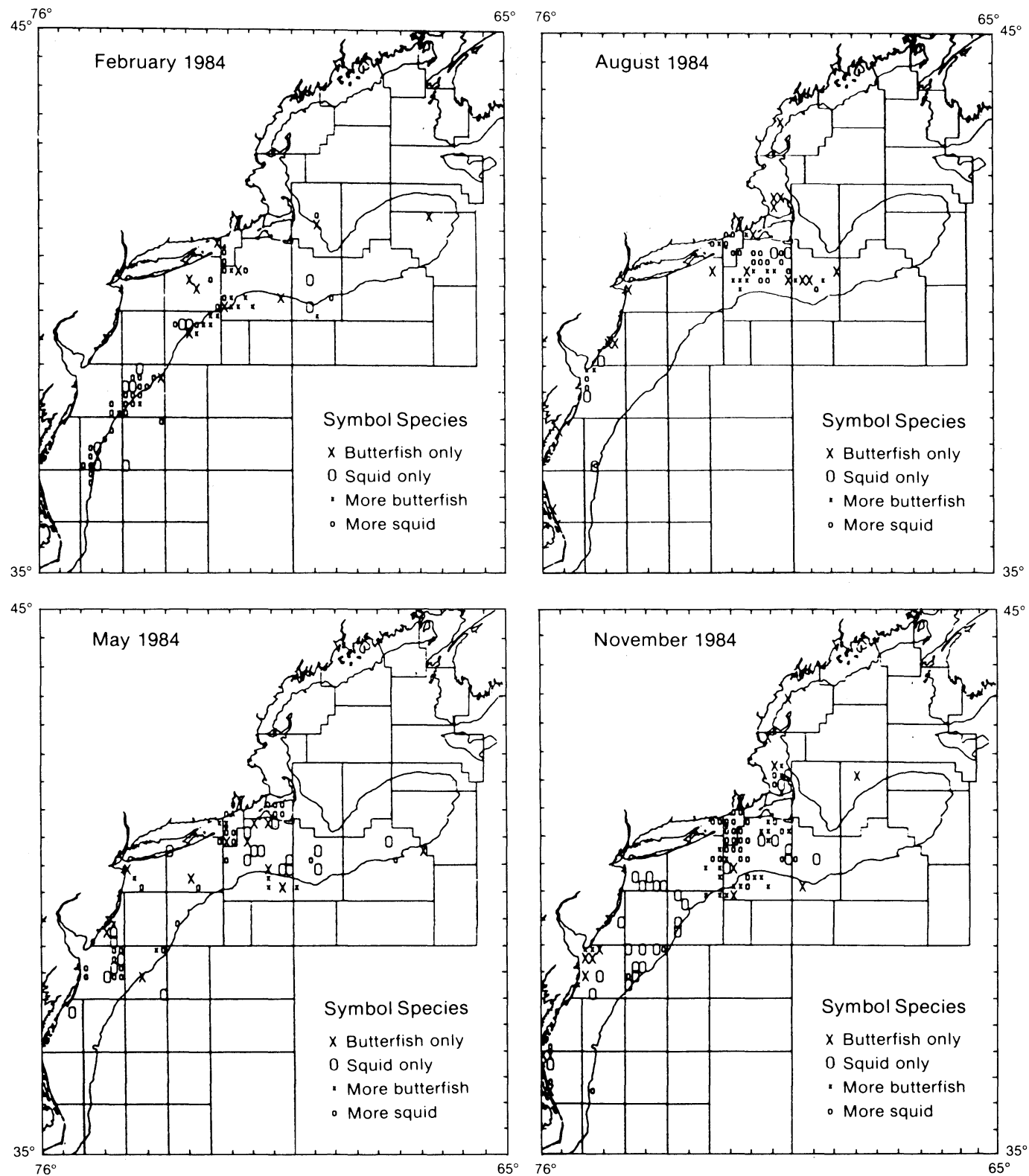

Fig. 3. Quarterly distribution of interviewed USA trips reporting landings of long-finned squid and/or butterfish. Large symbols indicate that all interviewed trips to that 10' square during the month reported only one of these two species (X-butterfish, 0-long-finned squid). Those 10' squares which produced catches of both species during the month are noted with smaller symbols indicating which species dominated landings. A species was considered dominant for all trips when the catch of that species was greater than the catch of the other species.

are statistical areas from Fig. 1, with the exception that area 43 occurs further north.

Spring surveys generally had the lowest percentage occurrence of each species/size-group (Fig. 4). Large squid were found most consistently of the four species/size-groups during this season. Area 63 provided the greatest proportions of tows with representatives from each species/size-group, which is consistent with the seasonal distribution of these species. The greatest proportion of tows containing each species/size-group occurred at a depth range of
111-185 m. Percentage occurrence decreased with decreasing depth for each species/size-group. Large and small butterfish were taken consistently among time periods (10-13\%). Large and small squid occurred in decreasing percentages of tows with decreasing ambient light, as reflected in catch by time period.

Summer surveys were conducted only during 1977-81, and focused on nearshore survey strata. Frequency distributions (percentage of tows) of occurrence by area, depth and time period show increased presence of each species/size-group compared to 

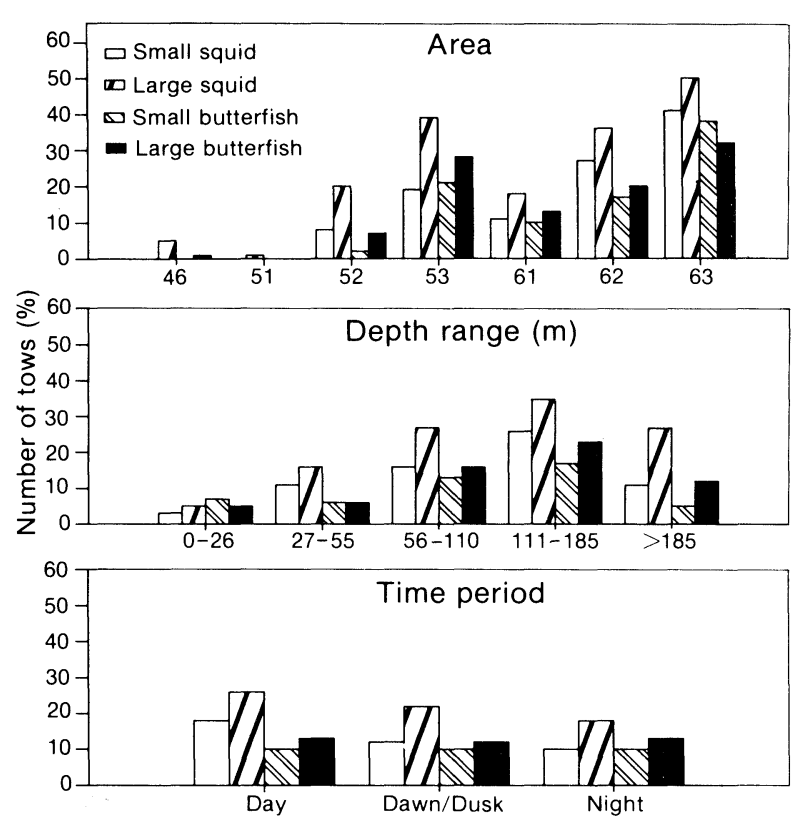

Fig. 4. Distribution (percentage) of spring survey tows containing each species/size-group used in the analyses of cooccurrence of long-finned squid and butterfish by area, depth and time period, 1976-85.
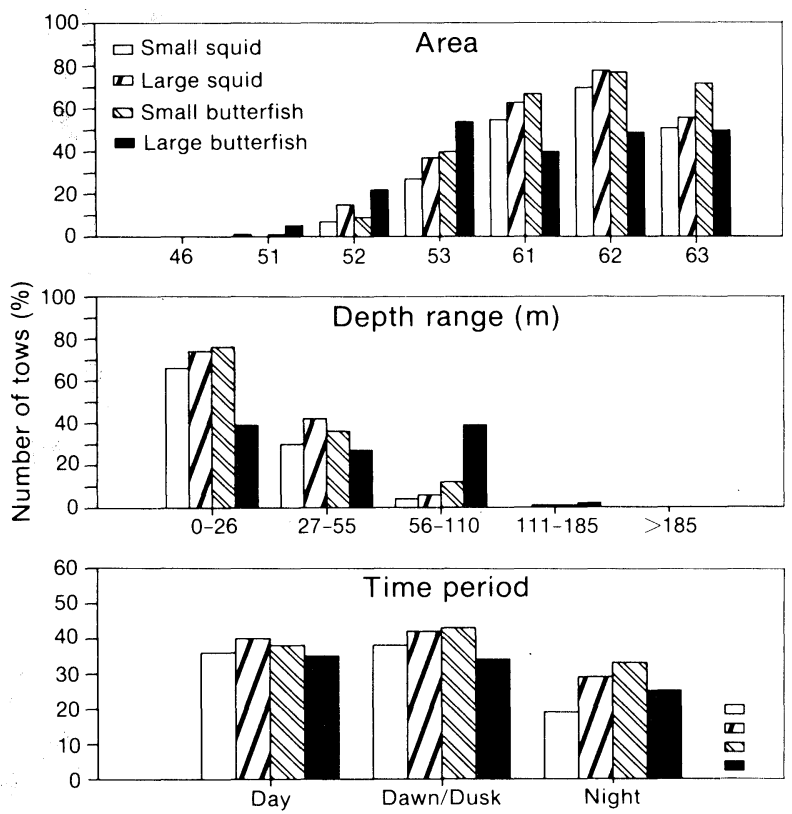

Fig. 5. Distribution (percentage) of summer survey tows containing each species/size-group used in the analyses of cooccurrence of long-finned squid and butterfish by area, depth and time period, 1977-85.

spring surveys (Fig. 5). Areas 61-63 had the highest occurrence of each species/size-group (over $50 \%$ of all tows) except large butterfish. The large butterfish group was the most consistently caught in area 53. Only $11 \%$ of summer tows were in depths over $111 \mathrm{~m}$
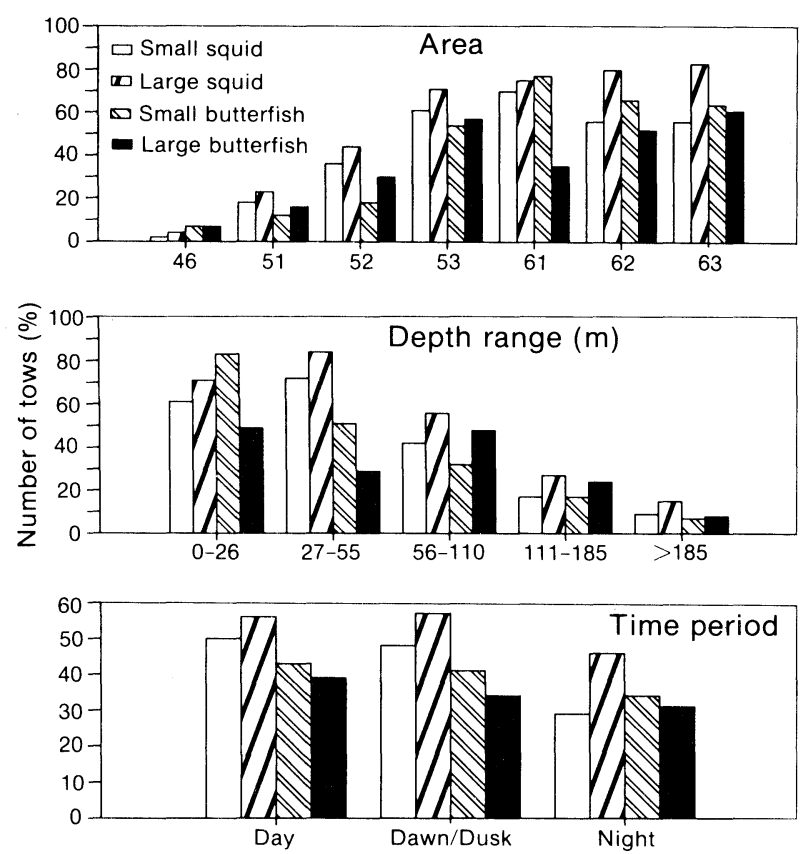

Fig. 6. Distribution (percentage) of autumn survey tows containing each species/size group used in the analyses of co-occurrence of long-finned squid and butterfish by area, depth and time period, 1976-85.

and very few of them caught squid or butterfish. Large butterfish was the only group occurring with regularity in the 56-110 m depth range. Large and small squid and small butterfish declined in occurrence with increasing depth during summer surveys. Diurnal patterns of availability to the survey trawl were also apparent. Each species/size-group was taken in a higher percentage in the day and dawn/dusk tows, than night tows during summer.

Autumn surveys indicated a shelf-wide dispersion of these two species, as the percentage of tows with each group in most areas was higher (Fig. 6), than in spring and summer. In areas 53 and 61-63, large squid occurred in $71-83 \%$ of the tows, small squid were taken in $56-70 \%$ of the tows, small butterfish in $54-77 \%$ and large butterfish in $35-61 \%$ of the tows. All species/ size-groups were available in all statistical areas. Highest percentages of tows in each group occurred in the shallower depth ranges during autumn (0-26 $\mathrm{m}$ and 27-55 m), each species/size-group was captured less frequently in depths greater than $55 \mathrm{~m}$. Percentage occurrences of each group were similar in the day and dawn/dusk tows, while occurrence during night was considerably less for large and small squid. Large butterfish were caught most consistently throughout the $24 \mathrm{hr}$ period (31-39\% of tows), although their frequency of occurrence did decrease somewhat in the night.

Generally, large butterfish had the highest proportion of zero tows of all the species/size-groups, and the 
TABLE 4. Model II regression parameters for relationships between (A) proportion of zero tows (PZ), (B)dispersion indices (DI) and catch-per-tow (mean number) for large and small long-finned squid and butterfish, from autumn NMFS bottom trawl surveys, 1976-85.

\begin{tabular}{llll}
\hline \hline Species/ & \multicolumn{2}{c}{ Parameter } & Confidence limits \\
\cline { 2 - 3 } & Intercept Slope & Lower Upoup & Slor Upper
\end{tabular}

A. Proportion of zero tows (PZ)

$\begin{array}{lllll}\text { Squid } & & & & \\ \text { large } & 0.4171 & -0.0027 & -0.0047 & -0.0009 \\ \text { small } & 0.3998 & -0.00005 & -0.0005 & -0.0003\end{array}$

Butterfish

$\begin{array}{llllr}\text { large } & 0.6533 & -0.0018 & -0.0048 & -0.0005 \\ \text { small } & 0.3833 & -0.00026 & -0.0013 & 0.0001\end{array}$

\section{B. Dispersion indices (DI)}

\section{Squid}

$\begin{array}{lrrrr}\text { large } & 0.0335 & 0.0005 & -0.0020 & 0.0046 \\ \text { small } & 0.0634 & -0.0001 & -0.0004 & 0.0005\end{array}$

Butterfish

\begin{tabular}{lllll} 
large & 0.0728 & 0.0002 & -0.0012 & 0.0008 \\
small & 0.0273 & 0.0002 & -0.00002 & 0.0009 \\
\hline
\end{tabular}

highest index of disperson (0.03-0.12), except in 1985 when small squid and butterfish exhibited more contagious distributions (Table 2). However, the DI values were very low (generally $\leqslant 0.10$ ) for all groups.

Relationships between autumn abundance indices and the dispersion indices, $\mathrm{PZ}$ and $\mathrm{DI}$, were tested to determine if spatial aggregation patterns changed in relation to variations in stock density. Model II regression by Bartlett's three-group method (Sokal and Rohlf, 1981) was used since both variables were measured with error. There was no significant relationship (the lower and upper confidence interval included zero) between the proportion of zero tows and abundance for small butterfish, while this relationship was significant for large and small squid and large butterfish (Table 4A, Fig. 7). Negative slopes in these relationships indicated that as abundance increased for large and small squid and butterfish, they were taken in a higher proportion of tows. Relationships between DI and species abundance were non-significant for all groups (Table 4B). The stocks did not exhibit marked changes in spatial dispersion relative to changes in density.

Seasonal weighted mean depths and temperatures of capture, by species/size-group, revealed a generally increasing trend in temperature for each group from spring to autumn (Table 5). Mean depth of capture decreased for each group between spring and summer,

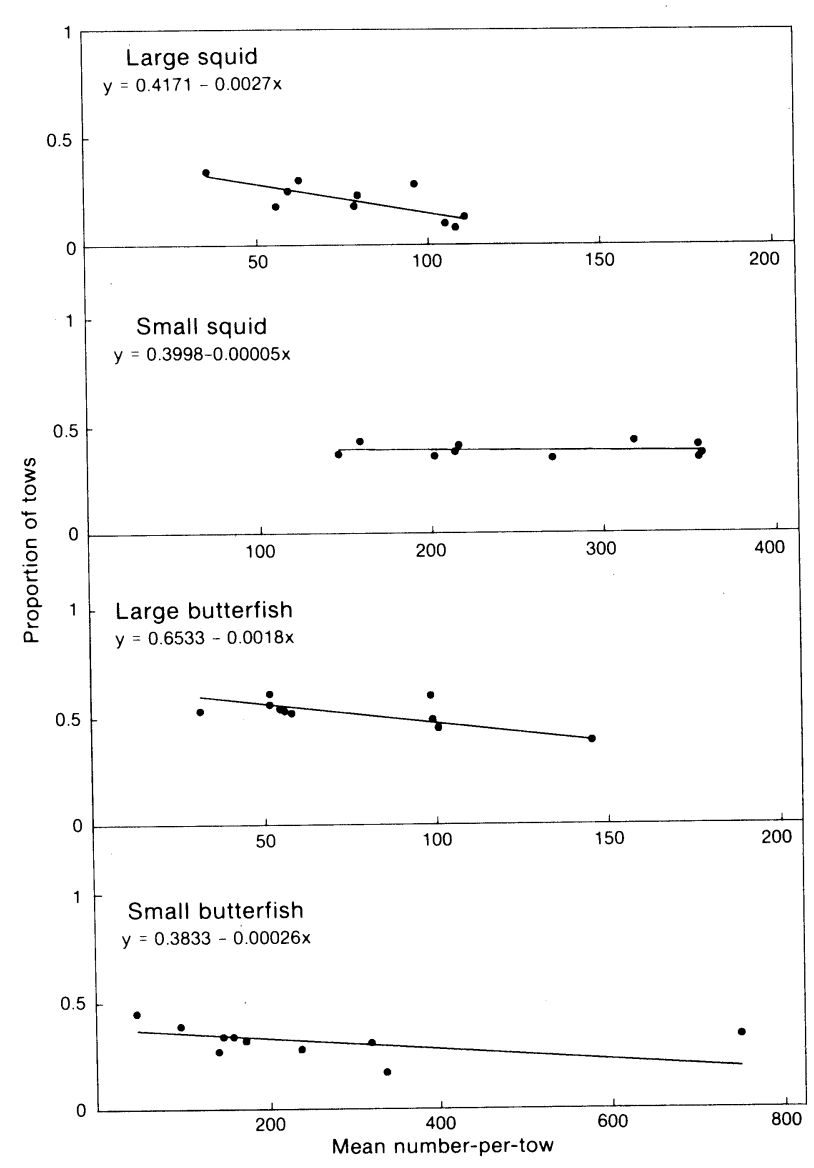

Fig. 7. Proportion of autumn bottom trawl survey tows not containing the species/size-group (proportion of zeros $=\mathrm{PZ}$ ) versus mean number-per-tow for large long-finned squid, small long-finned squid, large butterfish and small butterfish. Model II regression parameters are presented in Table 4A.

as the stocks moved inshore, and increased during autumn. Large squid and butterfish were generally found in deeper waters than were the smaller individuals. Squid and butterfish are migratory species which undergo seasonal movements, within relatively consistent temperature regimes, therefore, the cv for depth at capture were always greater than the corresponding cv for temperature. A clustering algorithm ('CLUSTER' in SAS, 1985) based on the average linkage method, was used to group the four size-groups based on weighted mean temperatures and depths of occurrence for each season. Each size-group was initially considered to be a separate cluster. Clusters were paired successively based on the shortest distance (degree of dissimilarity) between each pair. The analysis indicated that during spring, small squid and small butterfish were likely to co-occur, while large squid and large butterfish also occurred in similar temperaturedepth regimes, but at a greater distance than smaller individuals (Fig. 8). Overlap across size-groups was less likely. During summer, large and small squid and 
TABLE 5. Mean, standard deviation (sd) and coefficient of variation (cv) of depth and temperature at capture of large and small long-finned squid and butterfish, by season, during NMFS bottom trawl surveys, 1976-85. Means are weighted by catches (in number-per-tow).

\begin{tabular}{|c|c|c|c|c|c|c|c|}
\hline \multirow{2}{*}{$\begin{array}{l}\text { Species/ } \\
\text { size-group }\end{array}$} & \multirow[b]{2}{*}{ Season } & \multicolumn{3}{|c|}{ Depth $(\mathrm{m})$} & \multicolumn{3}{|c|}{ Temperature $\left({ }^{\circ} \mathrm{C}\right)$} \\
\hline & & Mean & sd & $\mathrm{cv}$ & Mean & $\mathrm{sd}$ & $\mathrm{cV}$ \\
\hline \multirow{4}{*}{ Squid/large } & All & 77.6 & 56.34 & 0.73 & 13.0 & 3.11 & 0.24 \\
\hline & Spring & 134.0 & 51.19 & 0.38 & 11.3 & 1.46 & 0.13 \\
\hline & Summer & 23.3 & 12.40 & 0.53 & 14.7 & 2.96 & 0.20 \\
\hline & Autumn & 68.6 & 45.86 & 0.67 & 13.3 & 3.31 & 0.25 \\
\hline \multirow[t]{4}{*}{ Squid/small } & All & 46.6 & 40.54 & 0.87 & 15.1 & 3.54 & 0.23 \\
\hline & Spring & 97.2 & 47.30 & 0.49 & 11.5 & 2.04 & 0.18 \\
\hline & Summer & 20.8 & 12.08 & 0.58 & 15.8 & 2.80 & 0.18 \\
\hline & Autumn & 41.0 & 32.50 & 0.79 & 15.8 & 3.45 & 0.22 \\
\hline \multirow[t]{4}{*}{ Butterfish/large } & All & 84.0 & 53.79 & 0.64 & 14.0 & 4.47 & 0.32 \\
\hline & Spring & 147.2 & 44.55 & 0.30 & 11.4 & 1.11 & 0.10 \\
\hline & Summer & 53.4 & 30.49 & 0.57 & 11.8 & 3.49 & 0.29 \\
\hline & Autumn & 70.9 & 44.52 & 0.63 & 15.3 & 4.75 & 0.31 \\
\hline \multirow[t]{4}{*}{ Butterfish/small } & All & 47.0 & 41.13 & 0.88 & 15.4 & 3.78 & 0.25 \\
\hline & Spring & 100.9 & 42.64 & 0.42 & 10.6 & 1.80 & 0.17 \\
\hline & Summer & 22.7 & 15.39 & 0.68 & 15.4 & 2.86 & 0.19 \\
\hline & Autumn & 53.0 & 42.10 & 0.79 & 15.8 & 3.97 & 0.25 \\
\hline
\end{tabular}

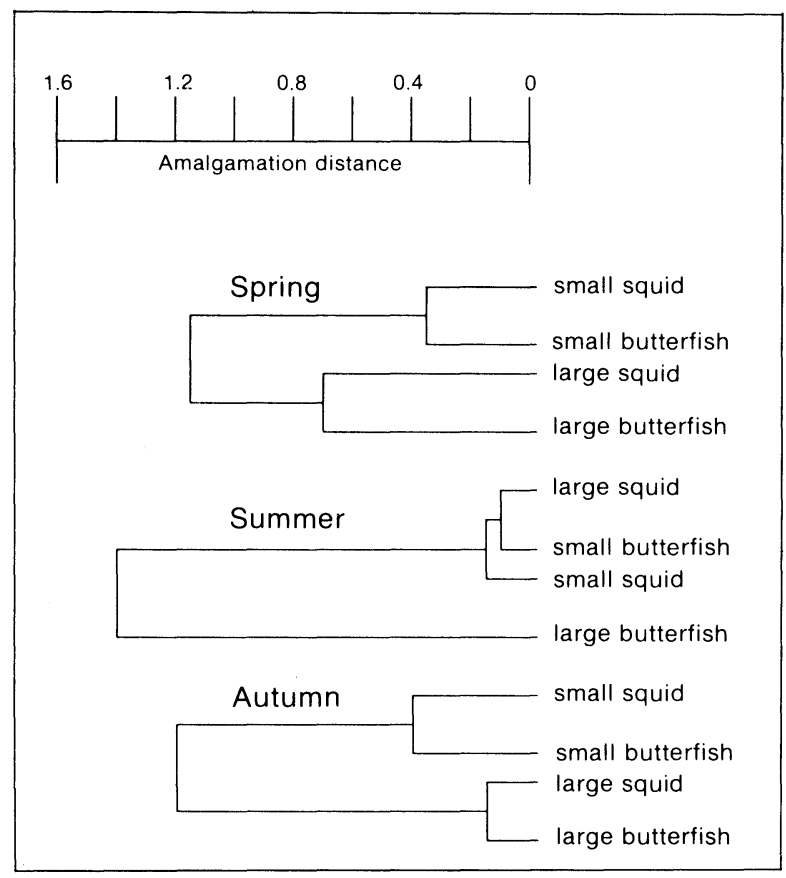

Fig. 8. Cluster analysis dendograms illustrating the relationships of long-finned squid and butterfish, by size, based on temperature and depth preferences, by season. Data from the NMFS bottom trawl survey, 1976-85.

small butterfish were clustered, while large butterfish were very distinct. Large squid and butterfish were similarly clustered during autumn, while small individuals were grouped at about twice that distance. Grouping of large versus small size-groups occurred at a much greater distance.
The basis for the cluster analysis results can be seen in the plots of seasonal mean temperatures ( \pm 1 sd of the distribution) against depth ( $\pm 1 \mathrm{sd}$ ) (Fig. 9).

Overlap coefficients were relatively high $(\geqslant 0.74)$ for temperature and depth preferences for each species-size pair, in most seasons (Table 6). Large butterfish during summer, however, exhibited lower overlap of depths with each of the other groups $(\leqslant 0.60)$, and in temperature preferences with small butterfish (0.72) and squid (0.67). Results of this analysis agreed with the cluster analysis and mean-sd plots described previously.

Results from seasonal survey data analyses indicated the potential difficulty of conducting a directed squid fishery without taking butterfish (at least small individuals). However, there are diurnal differences in distribution and catchability of each size-group. These differences were further tested by analyzing the survey data separately by time period of day. The proportion of tows with co-occurring species pairs varied somewhat among the three time periods (Fig. 10). For those tows taking large squid, the proportion of tows taking small squid or large butterfish was lower at night than during other periods. Those tows with small squid had similar proportions of large squid and small butterfish in each time period. Of those tows with large or small butterfish, the proportion of tows with each of the other groups declined at night. The most dramatic difference in proportion of tows with a co-occurring species/sizegroup for a given time period was for small squid, taken at night in tows taking each other species/size-group. This would corroborate the ability to conduct a 


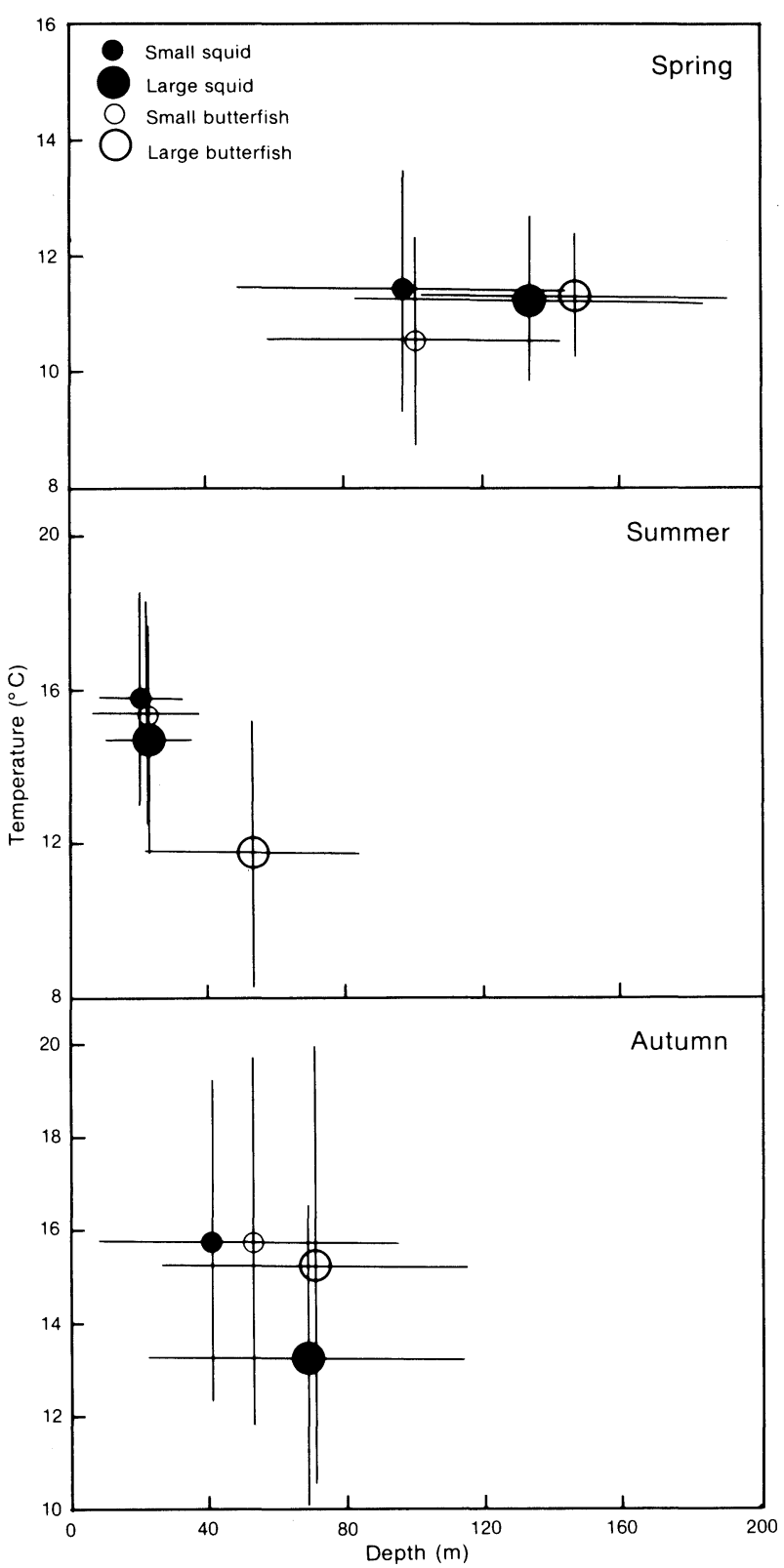

Fig. 9. Plots of weighted (by catch-in-number) mean temperature and depth of capture for large and small long-finned squid and butterfish, by season, including lines of one standard deviation on each axis.

"switch" fishery as described by Nagasaki (unpublished data), where small squid would likely not be taken in night tows where the other species/sizegroups are taken.

\section{Foreign fishery data}

Analyses of the foreign fishery data indicated the lowest percentage of tows with a by-catch of butterfish were during October-December (21-43\%), in area 3 $(35 \%)$, in depths between $56-110 \mathrm{~m}$ or over $185 \mathrm{~m}$ by
Italian and Spanish vessels (Table 3). Highest percentages of tows with a by-catch of butterfish were during January-March (82-76\%), in area $5(78 \%)$, in depths between 111-185 $\mathrm{m}$ and by Japanese vessels. Little difference was seen in by-catch percentages in the time period of day.

Coefficients of overlap in preferred depth as described for the survey data using equation 3, are provided in Table 7 . Lowest coefficients occurred in November in areas 2 and 4, and in March in area 3. However, since these were based on data collected in a directed squid fishery, the corresponding weighted mean depths for butterfish may have been biased toward the depths which were assumed to be preferred by squid. Also, the fishery was restricted to the foreign fishing windows which were themselves established, in part, by depth.

Further analyses provided information on the specifics of butterfish by-catch, including the proportion of the total catch comprised of butterfish. Data were summarized by country, month, area, depth range and time period. Proportionally few tows $(1.2 \%)$ caught no squid or butterfish, or reported catches of butterfish with no squid $(1.2 \%)$. Over $46 \%$ (1 100) had no butterfish by-catch associated with the squid catch, with most of those in area 3 (56-110 $\mathrm{m}$ depths) during November and December. Of those which took both squid and butterfish ( 1196 or $51 \%$ ), the amount of butterfish exceeded squid in only 42 tows (4\%). Most of those tows were made during January-March, and the butterfish catches were three times as large as squid.

The highest ratio (12.7) of butterfish to squid catch was seen during October in area 1, and in November in area 2 (11.6) (Table 8). However, the number of sampled tows in these areas/months were very low (3 and 9 , respectively). Summarized ratios exceeded 0.25 only in area 4 during September $(0.35,45$ tows) and December $(0.38,14$ tows), but were based on small sample sizes. Lowest by-catch ratios occurred during November in area 1 (0.01, only 4 tows), during August in area $2(0.003,34$ tows), during December in area 3 (0.02, 528 tows), during October in area $4(0.03,10$ tows) and during December in area 5 ( 0.03, 57 tows).

The allocation of butterfish to the foreign fleet fishing for squid has generally been based on an allowable by-catch equivalent to $6 \%$ of the allocated amount of long-finned squid (Atlantic mackerel, squid and butterfish Fisheries Management Plan of the Mid-Atlantic Fishery Management Council). The overall by-catch ratio for this sample was 0.07 of the total sampled squid catch. By country, the by-catch ratio was 0.07 for Spain (respresenting $69 \%$ of tows and $61 \%$ of catch), 0.14 for Japan ( $8 \%$ of tows and $13 \%$ of catch) and 0.03 for Italy (23\% of tows, $26 \%$ of catch). 
TABLE 6. Coefficients of overlap in environmental preferences between large and small, long-finned squid and butterfish, in the Southern New England and Mid-Atlantic areas, by season, from NMFS bottom trawl sampling, 1976-85.

\begin{tabular}{|c|c|c|c|c|}
\hline \multirow{2}{*}{$\begin{array}{l}\text { Species/ } \\
\text { size-group }\end{array}$} & \multirow[b]{2}{*}{ Season } & \multicolumn{3}{|c|}{ Overlap coefficients } \\
\hline & & Squid/large & Squid/small & Butterfish/large \\
\hline \multicolumn{5}{|c|}{ Depth } \\
\hline \multirow[t]{4}{*}{ Squid/small } & All & 0.88 & & \\
\hline & Spring & 0.87 & & \\
\hline & Summer & 0.99 & & \\
\hline & Autumn & 0.86 & & \\
\hline \multirow[t]{4}{*}{ Butterfish/large } & All & 1.00 & 0.84 & \\
\hline & Spring & 0.98 & 0.74 & \\
\hline & Summer & 0.55 & 0.51 & \\
\hline & Autumn & 1.00 & 0.84 & \\
\hline \multirow[t]{4}{*}{ Butterfish/small } & All & 0.89 & 1.00 & 0.85 \\
\hline & Spring & 0.88 & 1.00 & 0.75 \\
\hline & Summer & 0.99 & 0.98 & 0.60 \\
\hline & Autumn & 0.97 & 0.96 & 0.96 \\
\hline \multicolumn{5}{|c|}{ Temperature } \\
\hline \multirow[t]{4}{*}{ Squid/small } & All & 0.90 & & \\
\hline & Spring & 0.97 & & \\
\hline & Summer & 0.96 & & \\
\hline & Autumn & 0.87 & & \\
\hline \multirow[t]{4}{*}{ Butterfish/large } & All & 0.95 & 0.97 & \\
\hline & Spring & 0.98 & 0.91 & \\
\hline & Summer & 0.82 & 0.67 & \\
\hline & Autumn & 0.91 & 0.97 & \\
\hline \multirow[t]{4}{*}{ Butterfish/small } & All & 0.88 & 1.00 & 0.97 \\
\hline & Spring & 0.94 & 0.94 & 0.88 \\
\hline & Summer & 0.98 & 1.00 & 0.72 \\
\hline & Autumn & 0.88 & 1.00 & 0.99 \\
\hline
\end{tabular}

\section{USA interview data}

The total number of interviewed trips along with reported catches of squid and/or butterfish by area are presented in Table 9. Primary areas (those with the greatest number of trips) with reported catches of these species were Statistical Areas 537 and 539 (Fig. 11). The highest catch rates for squid occurred in areas 538 and 632, and for butterfish in areas 616, 537 and 526 .

Trips reporting catches of either or both species are summarized in Table 10. The greatest number of these 'pure' trips were reported in areas 621 and 612 for butterfish, and in area 537 for squid. By month, the greatest number of trips reporting squid alone occurred during November and December; while the highest percentage of trips reporting squid (which did not also report butterfish) and the highest catch rates for these 'pure' trips were during June. Butterfish were caught without squid more frequently during October, November and September than in other months, while highest catch rates in these 'pure' trips occurred in
February and January. The greatest proportion of trips reporting butterfish alone (relative to all trips reporting butterfish) occurred during August-October.

\section{Discussion}

The seasonal and temporal distributions of longfinned squid and butterfish based on NEFC broadscale survey data indicate a high degree of overlap in temperature and depth preferences. Comparisons of the proportion of tows which contained both species, by size-group, indicate that these preferences are associated with high degrees of co-occurrence in the survey tows, during most seasons and in most time periods of the day. Significant negative relationships between annual abundance indices and proportion of zero tows for large squid and butterfish suggest that these species/size-groups do not significantly aggregate or disperse with changes in abundance. If this is so, in years of high abundance, by-catch would be likely to increase in the fishery directed to the other species. 


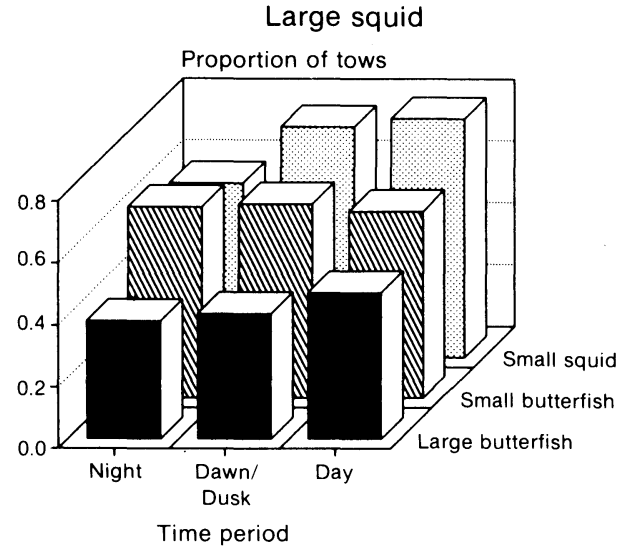

Large butterfish

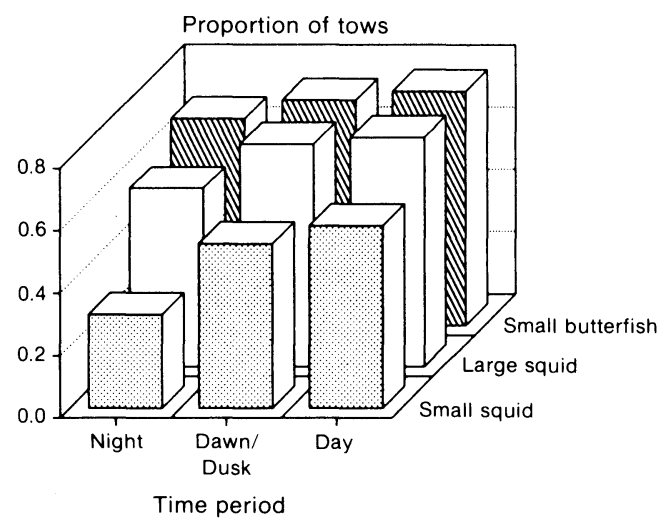

Small squid

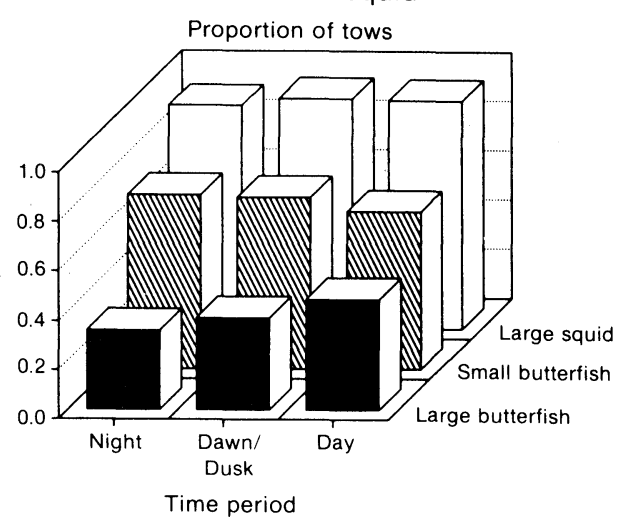

Small butterfish

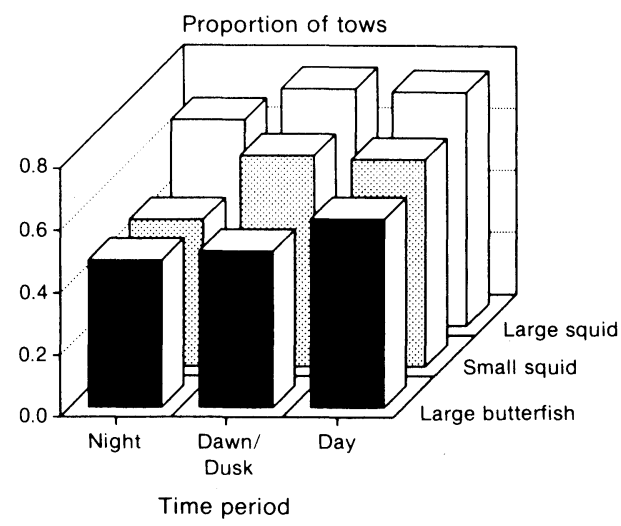

Fig. 10. Proportion of all tows which caught large long-finned squid, small long-finned squid, large butterfish and small butterfish, that also took each of the other species/size-groups, by time period.

TABLE 7. Coefficients of overlap in depth preferences between longfinned squid and butterfish, by area and month, based on a subset of data from the 1984 squid directed foreign fishery. Data are from the NMFS Foreign Fishery Observer Program.

\begin{tabular}{lccc}
\hline & \multicolumn{3}{c}{ Area } \\
\cline { 2 - 4 } Month & 2 & 3 & 4 \\
\hline Jan & 0.85 & 0.93 & 0.96 \\
Feb & - & 0.98 & 0.63 \\
Mar & 0.89 & 0.36 & 0.95 \\
Aug & 0.89 & - & - \\
Sep & 0.95 & - & 0.83 \\
Oct & - & 0.61 & - \\
Nov & 0.43 & 0.94 & 0.30 \\
Dec & - & 0.75 & 0.77 \\
\hline
\end{tabular}

Data from the 1984 squid directed foreign fishery which occurred in restricted areas along the shelf edge, showed that the lowest by-catch of butterfish, associated with relatively high catch rates of squid, could be expected during January in area $4(1000 \mathrm{~kg} / \mathrm{tow}$, ratio of 0.05) and during November and December in area 3 (over $800 \mathrm{~kg} / \mathrm{tow}$, with ratios of 0.03 and 0.02 , respectively). These low ratios were attributed to both low catches of butterfish in general and to high proportions of tows which took no butterfish.

The USA squid and butterfish fisheries encompass a broader area than occupied by the foreign fleet, but are concentrated in the southern New England-MidAtlantic region. Most trips which reported catches of one of these species, also landed the other. While $61 \%$ of the interviewed trips which landed butterfish also landed squid, $78 \%$ of the butterfish landings were from trips which caught squid. Fifty-nine percent of interviewed trips reporting squid landings during 1984 were from trips which also took butterfish (32\% of the total trips landing squid). In general, catch rates for each species were greater in those trips which took both species, than for those with only one species reported.

Nagasaki (unpublished data) reported the ability of Japanese fleets to direct effort at either squid or butterfish when these species inhabit the same grounds. Fine scale spatial separation, due to such factors as differential diurnal vertical migration may account for the ability to direct to one or the other species, even though the habitat preferences are, in general, very similar. 
TABLE 8. Catch and by-catch ratios of butterfish $(\mathrm{Bf} / \mathrm{Ls}=$ butterfish catch/long-finned squid catch) in the squid directed fishery during 1984 , by area and month. Data are from a subset of 1984 NMFS Foreign Fishery Observer Program trip records

\begin{tabular}{|c|c|c|c|c|c|}
\hline Area & Month & $\begin{array}{l}\text { No. of } \\
\text { tows }\end{array}$ & $\begin{array}{l}\text { Squid } \\
(\mathrm{kg})\end{array}$ & $\begin{array}{l}\text { Butterfish } \\
(\mathrm{kg})\end{array}$ & $\mathrm{Bf} / \mathrm{Ls}$ Ratio \\
\hline 1 & Oct & 3 & 252 & 3200 & 12.70 \\
\hline 1 & Nov & 4 & 4325 & 45 & 0.01 \\
\hline 2 & Jan & 50 & 70659 & 2039 & 0.03 \\
\hline 2 & Feb & 1 & 10 & 0 & 0.00 \\
\hline 2 & Mar & 120 & 246588 & 10923 & 0.04 \\
\hline 2 & Aug & 34 & 5047 & 18 & * \\
\hline 2 & Sep & 37 & 6181 & 1290 & 0.21 \\
\hline 2 & Nov & 9 & 1730 & 20085 & 11.61 \\
\hline 3 & Jan & 81 & 79628 & 3335 & 0.04 \\
\hline 3 & Feb & 114 & 122622 & 5778 & 0.05 \\
\hline 3 & Mar & 15 & 12132 & 2851 & 0.24 \\
\hline 3 & Oct & 203 & 212830 & 17106 & 0.08 \\
\hline 3 & Nov & 424 & 339880 & 11349 & 0.03 \\
\hline 3 & Dec & 528 & 468360 & 8033 & 0.02 \\
\hline 4 & Jan & 128 & 127994 & 6127 & 0.05 \\
\hline 4 & $\mathrm{Feb}$ & 240 & 251913 & 33503 & 0.13 \\
\hline 4 & Mar & 232 & 369636 & 45673 & 0.12 \\
\hline 4 & Sep & 45 & 3276 & 1147 & 0.35 \\
\hline 4 & Oct & 1 & 138 & 5 & 0.04 \\
\hline 4 & Nov & 10 & 4785 & 160 & 0.03 \\
\hline 4 & Dec & 14 & 5610 & 2116 & 0.38 \\
\hline 5 & Mar & 3 & 862 & 211 & 0.24 \\
\hline \multirow[t]{4}{*}{5} & $\mathrm{Dec}$ & 57 & 72190 & 2269 & 0.03 \\
\hline & Italy & 533 & 626993 & 21855 & 0.03 \\
\hline & Japan & 189 & 302369 & 44856 & 0.15 \\
\hline & Spain & 1631 & 1475574 & 110552 & 0.07 \\
\hline Total & & 2353 & 2405521 & 177263 & 0.07 \\
\hline
\end{tabular}

TABLE 9. Number of trips, total and mean catch-per-trip (metric tons) long-finned squid and butterfish, from the USA fishery interviews during 1984.

\begin{tabular}{|c|c|c|c|c|c|c|}
\hline \multirow[b]{2}{*}{ Area } & \multicolumn{3}{|c|}{ Long-finned squid } & \multicolumn{3}{|c|}{ Butterfish } \\
\hline & $\begin{array}{c}\text { No. of } \\
\text { trips }\end{array}$ & $\begin{array}{l}\text { Total } \\
\text { catch }\end{array}$ & $\begin{array}{l}\text { Mean } \\
\text { catch }\end{array}$ & $\begin{array}{c}\text { No. of } \\
\text { trips }\end{array}$ & $\begin{array}{l}\text { Total } \\
\text { catch }\end{array}$ & $\begin{array}{l}\text { Mean } \\
\text { catch }\end{array}$ \\
\hline 512 & & & & 1 & 0.02 & 0.02 \\
\hline 513 & & & & 7 & 0.12 & 0.02 \\
\hline 514 & 18 & 1.24 & 0.07 & 54 & 2.51 & 0.05 \\
\hline 515 & & & & 1 & 0.02 & 0.02 \\
\hline 521 & 3 & 0.15 & 0.05 & 5 & 0.03 & 0.01 \\
\hline 522 & 1 & 0.81 & 0.81 & 2 & 0.95 & 0.48 \\
\hline 524 & & & & 2 & 0.49 & 0.25 \\
\hline 525 & 11 & 2.07 & 0.19 & 6 & 0.65 & 0.11 \\
\hline 526 & 38 & 30.90 & 0.81 & 51 & 289.01 & 5.67 \\
\hline 537 & 572 & 873.43 & 1.53 & 575 & 3475.60 & 6.04 \\
\hline 538 & 80 & 422.46 & 5.28 & 49 & 5.08 & 0.10 \\
\hline 539 & 402 & 124.21 & 0.31 & 382 & 37.99 & 0.10 \\
\hline 611 & 84 & 11.98 & 0.14 & 91 & 9.50 & 0.10 \\
\hline 612 & 63 & 115.84 & 1.84 & 174 & 27.07 & 0.16 \\
\hline 613 & 41 & 49.19 & 1.20 & 35 & 9.50 & 0.27 \\
\hline 614 & 13 & 3.27 & 0.25 & 69 & 7.94 & 0.12 \\
\hline 615 & 5 & 1.97 & 0.39 & 2 & 0.09 & 0.05 \\
\hline 616 & 138 & 242.00 & 1.75 & 121 & 997.94 & 8.25 \\
\hline 621 & 144 & 65.79 & 0.46 & 306 & 42.76 & 0.14 \\
\hline 622 & 200 & 272.72 & 1.36 & 150 & 120.79 & 0.81 \\
\hline 623 & 1 & 0.50 & 0.50 & 1 & 0.20 & 0.20 \\
\hline 625 & 15 & 2.24 & 0.15 & 18 & 0.39 & 0.02 \\
\hline 626 & 74 & 150.14 & 2.03 & 61 & 8.84 & 0.14 \\
\hline 627 & 2 & 1.12 & 0.56 & 1 & 0.05 & 0.05 \\
\hline 631 & 14 & 1.00 & 0.07 & 16 & 0.83 & 0.05 \\
\hline 632 & 48 & 219.81 & 4.58 & 16 & 1.24 & 0.08 \\
\hline 635 & 1 & 0.01 & 0.01 & 1 & 0.02 & 0.02 \\
\hline Vial & 1968 & 2592.83 & 1.32 & 2197 & 5039.63 & 2.29 \\
\hline
\end{tabular}

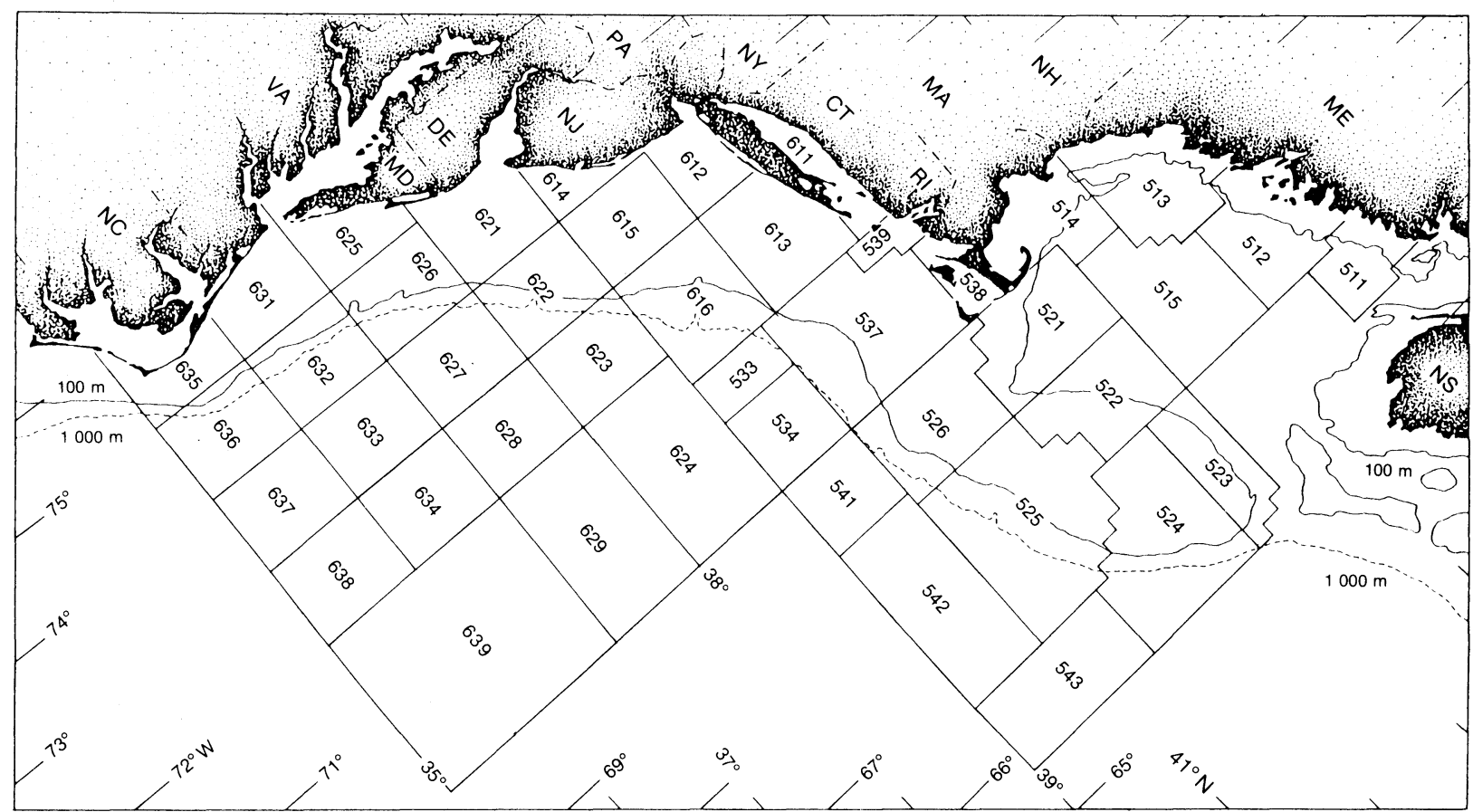

Fig. 11. USA Statistical Reporting Areas of the Northwest Atlantic. Three-digit statistical areas are grouped based on the first two digits (e.g. area 53 is comprised of statistical areas $533,534,537,538$, and 539 ). 
TABLE 10. Monthly distribution of the USA fishing trips reporting long-finned squid and/or butterfish interviewed during 1984.

\begin{tabular}{|c|c|c|c|c|c|c|c|}
\hline \multirow[b]{2}{*}{ Month } & \multicolumn{3}{|c|}{ Trips reporting catch of } & \multicolumn{2}{|c|}{ Trips with only } & \multicolumn{2}{|c|}{$\%$ pure trips $^{a}$} \\
\hline & Squid & Butterfish & Both & Squid & Butterfish & Squid & Butterfish \\
\hline Jan & 201 & 185 & 158 & 43 & 27 & 21.39 & 14.59 \\
\hline Feb & 160 & 158 & 123 & 37 & 35 & 23.13 & 22.15 \\
\hline Mar & 142 & 129 & 106 & 36 & 23 & 25.35 & 17.83 \\
\hline Apr & 113 & 94 & 78 & 35 & 16 & 30.97 & 17.02 \\
\hline May & 172 & 184 & 107 & 65 & 77 & 37.79 & 41.85 \\
\hline Jun & 133 & 142 & 65 & 68 & 77 & 51.13 & 54.23 \\
\hline Jul & 103 & 113 & 53 & 50 & 60 & 48.54 & 53.10 \\
\hline Aug & 94 & 155 & 62 & 32 & 93 & 34.04 & 60.00 \\
\hline Sep & 110 & 187 & 80 & 30 & 107 & 27.27 & 57.22 \\
\hline Oct & 150 & 292 & 110 & 40 & 182 & 26.67 & 62.33 \\
\hline Nov & 275 & 295 & 176 & 99 & 119 & 36.00 & 40.34 \\
\hline Dec & 315 & 263 & 226 & 89 & 37 & 28.25 & 14.07 \\
\hline Total & 1968 & 2197 & 1344 & 624 & 853 & 31.71 & 38.83 \\
\hline
\end{tabular}

a Percent of all trips reporting given species which did not also report the other species.

The USA domestic mixed-species fishery, with effort directed at either species at various times of the year, has not hereto been required to limit the catch of the other as by-catch. However, by-catch of small butterfish has been problematic to the USA butterfish fishery in recent years (NEFC, MS 1987). Analyses in this paper indicate that large butterfish are most separated from small butterfish during summer. Coincidently, summer is the period of low butterfish landings, mostly because vessels are targeting other species during that period. However, if a need develops to limit by-catch of either species by the domestic fishery, it is likely that seasonal, diel and areal management measures could be effective. Measures such as concentrating butterfish fishing in summer months, or at night, and in particular areas could be effective. Such measures may, however, require that the USA domestic fishery expand its operations beyond their traditional inshore southern New England - Mid-Atlantic fishing grounds.

\section{Acknowledgements}

We thank our colleagues at NEFSC for their reviews and helpful comments during our analyses and in preparation of this manuscript. We especially thank Dr S. Murawski and Mssrs. G. Shepherd and R. Mayo.

\section{References}

AZAROVITZ, T. R. 1981. A brief historical review of the Woods Hole Laboratory trawl survey time series. In: Bottom trawl surveys, W. G. Doubleday and D. Rivard (eds.). Can. Spec. Publ. Fish. Aquat. Sci., 58: 62-67.

ELLIOTT, J. M. 1977. Some methods for the statistical analysis of samples of benethic invertebrates. Freshwater Biological Assn. Publ., 25, $160 \mathrm{p}$

GREEN, R. H. 1966. Measurement of non-randomness in spatial distributions. Researches Popul. Ecol. Kyoto Univ., (1), 8: 1-7.

GROSSLEIN, M. D. 1969. Groundfish survey program at BCF Woods Hole. Comm. Fish. Rev., 31(8-9): 22-35.

MAY, R. M. 1973. Stability and complexity in model ecosystems. Monogr. in Popul. Ecol. Princeton Univ. Press. $235 \mathrm{p}$.

MURAWSKI, S. A., and J. T. FINN. 1988. Biological basis for mixed-species fisheries: species co-distribution in relation to environmental and biotic variables. Can. J. Fish. Aquat. Sci., 45: 1720-1735.

NEFC. MS 1987. Report of the Fourth NEFC Stock Assessment Workshop. NMFS/NEFC Lab. Ref. Doc., No. 87-07, $102 \mathrm{p}$.

SAS. 1985. User's Guide: Statistics. ver. 5 SAS Institute, Inc. Cary, N.C. 956 p.

SOKAL, R. R., AND F. J. ROHLF. 1981. Biometry, The Principles and Practice of Statistics in Biological Research, 2nd Edition. W. H. Freeman and Company. San Francisco. $859 \mathrm{p}$. 